\title{
FACTORS AFFECTING MATERNAL MORTALITY IN AN ALERT VILLAGE IN SOUTH TIMOR TENGAH, EAST NUSA TENGGARA
}

\author{
Belandina Nggadas, Rafael Paun, dan Mindo Sinaga \\ Masters Program in Public Health, Nusa Cendana University, Kupang
}

\begin{abstract}
Background: Maternal mortality may be attributable to direct or indirect causes, such as social, cultural, economic, and geographical factors. The purpose of this study was to determine factors affecting the risk of maternal mortality in an alert village in South Timor Tengah, East Nusa Tenggara.

Subjects and Method: This was a case control study conducted at a Community Health Center, in an alert village, South Timor Tengah, East Nusa Tenggara. A sample of 167 postpartum women, consisting of 35 dead postpartum women (represented by their families) and 132 alive postpartum women, were selected for this study. The independent variables were age, antenatal care visit, unskilled birth attendant, access transportation, and social support. The dependent variable was maternal death. The data were collected from medical and obstetric record and questionnaire. The data were analysis by multiple logistic regression.

Results: Risk of maternal mortality increased by birth delivery at home (OR $=18.00 ; 95 \% \mathrm{CI}=5.00$ to $74.00 ; \mathrm{p}=0.001)$, unskilled birth attendant $(\mathrm{OR}=$ $43.50 ; 95 \% \mathrm{CI}=4.40$ to $363.50 ; \mathrm{p}=0.001)$, antenatal care visit $<4$ (OR $=$ 50.09; $95 \% \mathrm{CI}=5.96$ to $420.40 ; \mathrm{p}=0.001$ ), maternal age $<20$ years or $\geq 35$ years $(\mathrm{OR}=3.29 ; 95 \% \mathrm{CI}=1.10$ to $9.05 ; \mathrm{p}=0.032)$, poor access to transportation $(\mathrm{OR}=4.5 \mathrm{O} ; 95 \% \mathrm{CI}=1.10$ to $18.50 ; \mathrm{p}=0.028)$, weak familly support $(\mathrm{OR}=3.05,95 \% \mathrm{CI}=1.05$ to $8.84, \mathrm{p}=0.037)$, and weak emotional support $(\mathrm{OR}=11.00 ; 95 \% \mathrm{CI}=3.2$ to $36.70 ; \mathrm{p}=0.001)$.

Conclusion: Risk of maternal mortality increased by birth delivery at home, unskilled birth attendant, antenatal care visit $<4$, maternal age $<20$ years or $\geq 35$ years, poor access to transportation, weak familly support, and weak emotional support.
\end{abstract}

Keywords: Maternal mortality, unskilled birth attendant, antenatal care, maternal age, transportation, familly support, emotional support

Correspondence:Belandina Nggadas. Masters Program in Public Health, Nusa Cendana University, Kupang, East Nusa Tenggara.

Email: nggadasbelandina@gmail.com. Mobile: +6281339323202. 